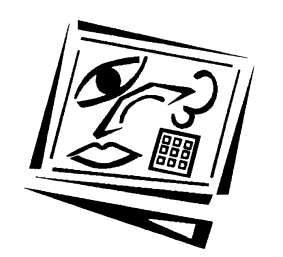

\title{
Incorporating Internet resources into classroom practice: Secondary school teacher action plans
}

\author{
Elena Ramírez, María Clemente, Isabel Cañedo and Jorge Martín \\ University of Salamanca
}

\begin{abstract}
Knowing precisely how teachers use Internet resources in their classroom practice is essential when seeking to explain what aspects support the real incorporation of information and communication technologies (ICT) in teaching, and in determining the mechanisms underlying the use of these resources in direct teaching situations. This article examines how five secondary school teachers assimilated different Internet resources into their teaching practice. Using a system for analysing classroom interaction that allowed us to segment teaching practice into categories differentiated by their level of generality, we studied the recordings of five class sessions in which Internet resources were used. The results show that common patterns existed in the way these teachers handled their sessions. The most outstanding pattern showed the overriding importance of curricular tasks and contents in the class sessions, and the subordination of the ICT resources to these curricular elements. It is also important to underscore the appearance of one type of task performance activity with ICT in all the sessions analysed, although more analysis about this activity is needed. The results pose challenges for the development of future research regarding consistency in the patterns of action found.
\end{abstract}

\section{Introduction}

In this article we present the results from analysing five secondary education class sessions. The teachers involved were from different specialisations and were video recorded while teaching in the classroom using a teaching resource associated with the Internet. We started from the premise that documenting what teachers actually do in their classroom practice when using Internet resources is essential when attempting to explain the foundations of the real incorporation of information and communication technologies (ICT) into teaching and to determine the mechanisms underlying their use in direct teaching situations.

In previous works we approached the study of secondary education teachers' use of ICT resources in Spain from a quantitative point of view, for which we employed questionnaires. This enabled us to learn what teaching tasks digital resources were used for, what specific resources were introduced into teaching practice, and to establish relations between the characteristics of the teachers, such as their professional experience, their training, and their attitudes towards ICT and other elements such as the organisational and structural conditions of the secondary schools, ICT practices, and teachers' reasons for using digital media, among others. The results obtained from these studies turned out to be useful for outlining some general characteristics of Internet use on the part of secondary school teachers. However, these findings shed 
little light on the real configuration of real practice, and posed doubts as to the direction of the causal relationships among the variables.

These problems led us to posit the study we describe herein, with the idea that if we can explain the particular conditions underlying the use of these resources in real teaching practice, we can then build practical knowledge for their optimum use. Moreover, as part of the theoretical suppositions, we revisit the ideas from research on teacher thinking (Clark, 2003), because although there is abundant research on ICT resources, we believe that a sufficient theoretical basis is still lacking to explain the professional reasons for incorporating these resources into real teaching practice, apart from the outcomes obtained in studies focused on innovation processes. We consider that assumptions about research into teacher thinking have evolved in a way that provides us with a stronger foundation to explain what goes on in real teaching practice, in the sense that Yinger (1987, p. 314) calls "the language of practice".

First of all, we describe the theoretical approaches and the accumulated knowledge that serve as a foundation for the study. Secondly, we present how the study was carried out, and the conclusions drawn.

\section{Theoretical assumptions}

In approaching this research we found particularly helpful the contributions of experts such as Loveless (2003) and Koehler \& Mishra (2009), because they explain teachers' adoption of ICT using the idea called 'teacher professional knowledge' (Shulman, 1986, 1987). In line with Shulman's approach, Loveless considered that the pedagogical knowledge of the discipline, one of the components of teacher professional knowledge, is the key to understanding the role of ICT as resources for appropriately presenting contents to the students. Discerning what aspects of ICT form part of this pedagogical knowledge of the subject matter is, in synthesis, one of the aims of this research, because it will allow us to explain whether teachers use these resources or not, and above all, how they use them and how they integrate them in their classroom practice. However, this perspective on professional knowledge should be accompanied by an analysis of the conditions in which teaching practice takes place, as we are trying to study the very action of teaching in natural scenarios.

Therefore, we add the idea of 'action plans', contributed by Leinhardt \& Greeno (1986) and Leinhardt, Weidman \& Hammond (1987), to the approach proposed by Loveless. The intention is to explain the mechanisms that teachers put into practice when handling complex and dynamic contexts whose objectives are not always clearly defined ... such as in the classroom. These action plans then become standards of professional behaviour that affect different types of academic activity, among them classroom performance (Gimeno, 1988). These actions gradually become professional routines that allow the teacher to take courses of action concerning the structured behaviour of students and teachers through goal-oriented activities. Practical plans guarantee the orderly development of the action and economise on effort, making predictable implementation possible in complex environments such as the classroom. According to Gimeno (1988), action plans are not only important in direct teaching practice, but also in other professional actions. In fact, these plans undoubtedly influence the curricular design and planning stage. A similar premise underpins the notion propounded by Putnam and Borko (2000, p. 13), whereby teachers' knowledge is linked to the context associated with characteristic features of the classes and the 
activities undertaken within them, and organised around tasks the teachers undertake within the classroom environment, and which they use over and over again for similar situations. The idea that action schemes are used by teachers for planning and direct teaching tasks in the classroom ties up with the definition of activity structures/types of activity, as described by, for example, Windschitl (2004. p. 25).

Studies regarding action plans have highlighted different elements as to their focal points. Carter and Doyle (1987) and Doyle (1987) point to tasks as the instrument for directing class actions, as they also serve to translate the curriculum into practical activities for a long period of time. This central role of tasks, identified as generic activities, has also been underscored in other papers, for example in Yinger (1977) and Tillema (1984). Contents have also been proposed as the structuring element of action plans, although always in close relation to tasks or activities (Shavelson \& Stern, 1983; Zahorik, 1975). The basic dimensions of each task or activity are, according to Shavelson and Stern (1983), content, some materials to use, particular actions of teacher and students, general but functional objectives, the conditions of the student, and the socio-cultural contexts of instruction.

Materials (among which we include ICT media and Internet resources) form one of the dimensions supporting the structure of tasks or activities: in short, practice; although, practice is more than the use of materials. Indeed, in the studies that have analysed this topic, different focal points have emerged around which teaching actions incorporating technologies may revolve. For example, Ellis et al. (2008) discuss the integration of the available resources within learning activities that can exploit the particular possibilities of each type of resource. Other studies (Zhao, Frank \& Ellefson, 2006) have underscored the connection between the incorporation of technologies and whether teachers have the kind of knowledge that enables them to translate the technological capabilities of digital resources into ways of solving their pedagogical problems - problems that are local in nature and strongly linked to the teaching contexts. In line with this, the study by Wells (2007) highlights how the success of professional development plans for teachers with respect to ICT depends on two characteristics: the plans must be focused on the learner and offer her or him a high degree of participation. This kind of participation would focus on matters such as having teachers analyse their lesson plans and identify potential applications of ICT resources. From a different perspective, the research done by Cuban $(1993,2001)$ regarding this topic found that computers in teaching were used predominantly as a medium for collecting and storing information, a use that perpetuates the most consolidated practices involving classical classroom media.

In light of all this, two key aspects can be emphasised: first, the incorporation of ICT resources into classroom practice will depend on the teacher's pedagogical knowledge of the discipline, specifically on the intersection between that knowledge and knowledge of ICT; and second, it will also depend on whether these resources make sense or not within the 'action plans' that the teacher is using to manage his or her activity in direct teaching.

\section{Research design}

\section{Research objectives}

In the previous section, we have described the theoretical propositions concerning teachers' use of the Internet and associated resources. Based on these premises, we 
propose to analyse how teaching is carried out using these media in direct teaching contexts, describing what is done with the classroom activities, the actions carried out and their relation to the most important elements of the curriculum: contents, objectives, tasks, and assessment. By means of this analysis we hope to locate the role of ICT within the teachers' action plans and in relation to their knowledge of the subject. Specifically, we analyse the following issues:

1. What is the methodological strategy that guides the classes? This strategy can be characterised by studying what the system of analysis used calls "typical classroom activities" (TCA). To this we add analysis of the instructive actions of the teachers, which serve to delimit the role of the teacher within the methodological approach deployed. The system of analysis employed is explained in more detail in the section on "class analysis procedure" below.

2. What role does the teacher give to the digital resource in relation to the rest of the curricular elements around which the classroom activity is developed? Analysis of the relation between typical classroom activities and the so-called "primary and secondary curricular elements" of each session allow us to locate where, when and how much the ICT resource is used in real practice.

Before describing the research, we must underscore an important matter that cannot be overlooked and that has been addressed directly in the research, although not mentioned specifically in this theoretical introduction. We refer to the role that the structural and organisational variables of the teaching context play in the effect that ICT have on teaching practices, a topic that has been dealt with in much previous research (Ruthven, Hennessy \& Deaney, 2005; Baek, Jung \& Kim, 2006; Baskin \& Williams, 2006; Cartwright \& Hammond, 2007; Bate, 2010). In this study we will refer to these structural and organisational variables when describing the video recorded class sessions, but when focusing on the analysis of the direct teaching in classroom practice, this context serves only as an interpretative framework for ICT practices.

\section{Participants}

We video-recorded five complete class sessions in secondary education (Spain) taught by five different teachers in the following subjects: English as a Foreign Language, Mathematics, Spanish Language and Literature, Classical Culture, and Philosophy (second quarter in the 2010 school year). All five teachers participated voluntarily and the classes were chosen randomly. Four of the five teachers were highly experienced, whereas the Philosophy teacher was just beginning her professional career. We informed them that we were interested in video recording classes in which they used some kind of Internet resource while teaching topics related to their field. At no time did we suggest either the resource to use or the topic to be taught; both of these decisions were left up to each teacher according to their own customary teaching organisation and planning. We then agreed on which class to record, taking into consideration their teaching schedule. Our intention was to collect data regarding their classroom practices involving the Internet and one class session was considered sufficiently representative. The procedure followed in all the cases was as follows:

- Each of the five sessions lasting approximately 50 minutes each were recorded in video and audio.

- On the date agreed for recording the session, sufficient time was scheduled before the class to set up the recording equipment in the classroom and to interview the 
teacher about aspects relating to the planning of this particular lesson. This was done in order to gather data for the structural and organisational variables.

- After the class was over, the teacher was interviewed as to his or her own assessment of the class session that had just ended, and a live audio recording was made of this interview.

All the audio and video recordings were transcribed in order to analyse the data, and thus we had available the texts of all the interviews, as well as of the video and audio recordings.

The data regarding the participants and the structural and organisational elements framing the teaching practices are presented in Appendix 1 below. We believe these data are necessary for interpreting the recorded class sessions incorporating Internet resources. It must also be noted that in the educational stages at which the data were collected, the official curriculum in Spain has introduced the compulsory creation of teaching spaces especially devoted to working with ICT (in fact, there are regulations regarding the characteristics that the computer classroom must have and its obligatory use in all schools (Royal Decree 1537/2003, 5 December). It has also adopted recommendations to develop ICT-related skills in the students that span the different curricular areas (Decree 52/2007, 17 May, art. 5.7). However, these transversal skills are not specifically mentioned in the outcomes the students are expected to have when completing the compulsory stages of education. The contents and applications of computer science are only dealt with specifically in the case of the subject "Computer Science" in compulsory secondary education (Decree 52/2007, 17 May, art. 5.3 and 6.3).

\section{Class analysis procedure}

In order to study the five recorded classes, we adapted the system for analysing educational practice developed by a research group at the University of Salamanca (Sánchez, García, Castellano, de Sixte, Bustos \& García Rodicio, 2008; Sánchez, García \& Rosales, 2010), the structure and sense of which can be consulted in Sánchez, García, Rosales, de Sixte and Castellano (2008); and Sánchez, García and Rosales (2010). The application of this system has led to a breakdown and analysis of what happens in classrooms, establishing categories for the study of the practice that shed light on the types of activity that inform the teachers' performance, the role of the different components of the curriculum in shaping the practices, and the parts most frequently played by teachers [1].

The system of analysis allows breaking down the recorded sessions into several categories. First, to segment the interaction, we divided the class sessions into units of analysis that allow us to observe the overall structure of the session by identifying typical classroom activities (TCAs): "planning activities," "assigning new tasks," "explaining the resource", "assigning homework". This unit of segmentation is called the "prototypical classroom activity" (Lemke, 1990, p. 50), whereby each classroom session is structured around successive TCAs that trace the general outline upon which pupils and teachers organise their classroom work.

In the TCA we differentiate another unit of analysis which we call episodes. These episodes are structures or segments of the interaction that define a goal or objective that can be perceived or identified by the participants (teachers and students) and form part of a more extensive segment that comprises the class activities (Sánchez, García, 
Castellano, de Sixte, Bustos \& García- Rodicio, 2008). In the episodes, another level is analysed which includes the actions of the teacher that are involved in attaining the objective of the episode. Thus, we divide the class sessions into segments defined by the objective they are seeking to attain. For example, we have a set of tasks for planning or explaining the ICT resource, which in turn are carried out with more specific goals in mind, such as the supervision of knowledge about the resource in question, or the explanation or performing of tasks.

In order to understand more precisely what exactly is going on in the class sessions analysed and to study the relations between the Internet resource and the teacher's action plan, we break down the teacher's action into two different groups of factors. On the one hand, we have those dealing with tasks involving learning - explaining concepts, namely, identifying, planning, explaining, recapitulating, and supervision assessment (Sánchez, Rosales \& Cañedo, 1999), and on the other, those related to curricular elements: objectives, tasks, contents, ICT resources and non-ICT resources (Gimeno, 2010). The interrelation of these two groups of factors gives rise to the group of categories that we used to analyse the teachers' actions. Below, we define what type of statements each of these categories refers to [2].

A. Identifying: This refers to statements that indicate or point things out about the elements in question, be they objectives, contents, tasks or resources. Some examples of this type would be: "Let's have the chorus, yes!" (Class 1: Identify taskresource). "Now go to the page to see if the Internet connection is working, you know what it is, http: / / www.nortedecastilla.es/" (Class 3: Identify resource).

B. Explaining: This refers to statements devoted to clarifying to a greater or lesser extent the elements in question, be they objectives, contents, tasks or resources. Some examples of this type would be: "Let's do something, at the same time that you've got that open, you can open a Word document like we've done before with Astronomy and I want you to start pasting there certain things that you bring up so you don't have to back track on the Internet, okay? Whatever you think is important, start copying it." (Class 4: Explain task-resource). "Miguel Ángel, 90 degrees. You can't forget that. 90 degrees. Why? Because it's the reference: if it's larger than 90 it's obtuse; if it's smaller, then it's acute" (Class 2: Explain content).

C. Planning: This refers to statements addressed to organising the elements in question in relation to goals and means, be they objectives, contents, tasks or resources. Some examples of this type would be: "So we are going to divide the activity into two parts and I'm going to do a short presentation of the controversy to bring us up to the year 2005. Then we're going to see a segment of a Simpson's episode to present this polemic and finally we're going to do an Internet search in groups" (Class 5: Plan task-resource). "Now that you've heard it we're going to try to associate it, you see? And I'm going to pause the image whenever I want, to see if we can learn to sing it a little, I can hardly hear you." (Class 1: Plan task-objective).

D. Recapitulating: This refers to statements devoted to reminding, repeating and/or updating in the sense of clarifying or organising the elements in question, be they objectives, contents, tasks or resources. Some examples of this type would be: "We were seeing what Man is, we' $\mathrm{d}$ seen the evolutionist positions, we' $\mathrm{d}$ seen the theory, they had examined previous knowledge about evolutionism, we' $\mathrm{d}$ also looked at taxonomy since Linnaeus" (Class 5: Recapitulate content). "Next ... triangles 
... classification of triangles. Let's remember this... We've also been looking at this ... at what a regular polygon is" (Class 2: Recapitulate content-resource).

E. Supervise-assess: This refers to statements addressed to more or less openly controlling the attainment of and/or progress in the elements in question, be they objectives, contents, tasks or resources. Some examples of this type would be: "What is 'sitting'? What's 'I'm sitting'? What's 'I'm sitting'? 'I'm sitting' ... how do you say in Spanish 'I'm sitting'?" (Class 1: Supervise content). "What's the matter, Miguel? Let's see; one plus one, two; and four fourths ... How much does four fourths make?" (Class 2: Supervise content-resource).

With respect to the curricular elements that the teacher works on during the class interaction, two levels can be distinguished, primary and secondary, reflecting the many occasions on which a teacher working with a primary curricular element uses a secondary curricular element as support or a resource for presenting the tasks and the contents. This situation is also very common when teachers use ICT. An example of this would be: "And then when I finish, I'll tell you about a Creationist web page called 'Sedin', and you'll be able to see the arguments Creationism uses to reject Evolutionism" (Class 5: Plan task-ICT resource). "Good, Adrian has done a sketch; I'm going to try and make it a little smaller so you can see it. He's chosen the title of the newspaper, Vox Populi 81, right? Would you explain it, Adrián?" (Class 4: Supervise task-resource ICT).

Thus, the procedure followed to analyse the classes is summarised in Figure 1, which indicates a three stage process:

1. Division of the class session into TCA, that is, the general activities that give the class structure.

2. Segmentation of the TCA into episodes defined by the goal or objective underlying the set of interactions comprising them, within the structure defined by the TCA.

3. Within each episode, identification of the actions that the teacher carries out in order to gradually build each segment of interaction within his or her classroom practice. By inter-judge agreement, we established as a criterion for segmentation of the actions, namely a change occurring in the teacher's action, either in the content of the action (from planning to explaining), in the primary curricular element involved in the action (from contents to tasks), or in the teacher's interlocutor (from the group to one student, from one student to another, etc.).

The sequence developed for applying the analysis system to the transcribed class sessions was as follows:

a. A class session is categorised simultaneously by three members of the research team trained in the system, in order to reach agreement regarding the contents of the categorisation.

b. The six members of the research team work in pairs to categorise another of the class sessions involved in the study.

c. The six members of the research team work individually to categorise the rest of the class sessions.

d. A review is made of the degree of agreement in the categorisation of the classes analysed, and, when necessary, agreements are reached regarding the discrepancies that may arise, until a univocal categorisation is attained. This stage began with an 
agreement rate surpassing $84.2 \%$ for individual categorisations and $100 \%$ in the final joint categorisation.

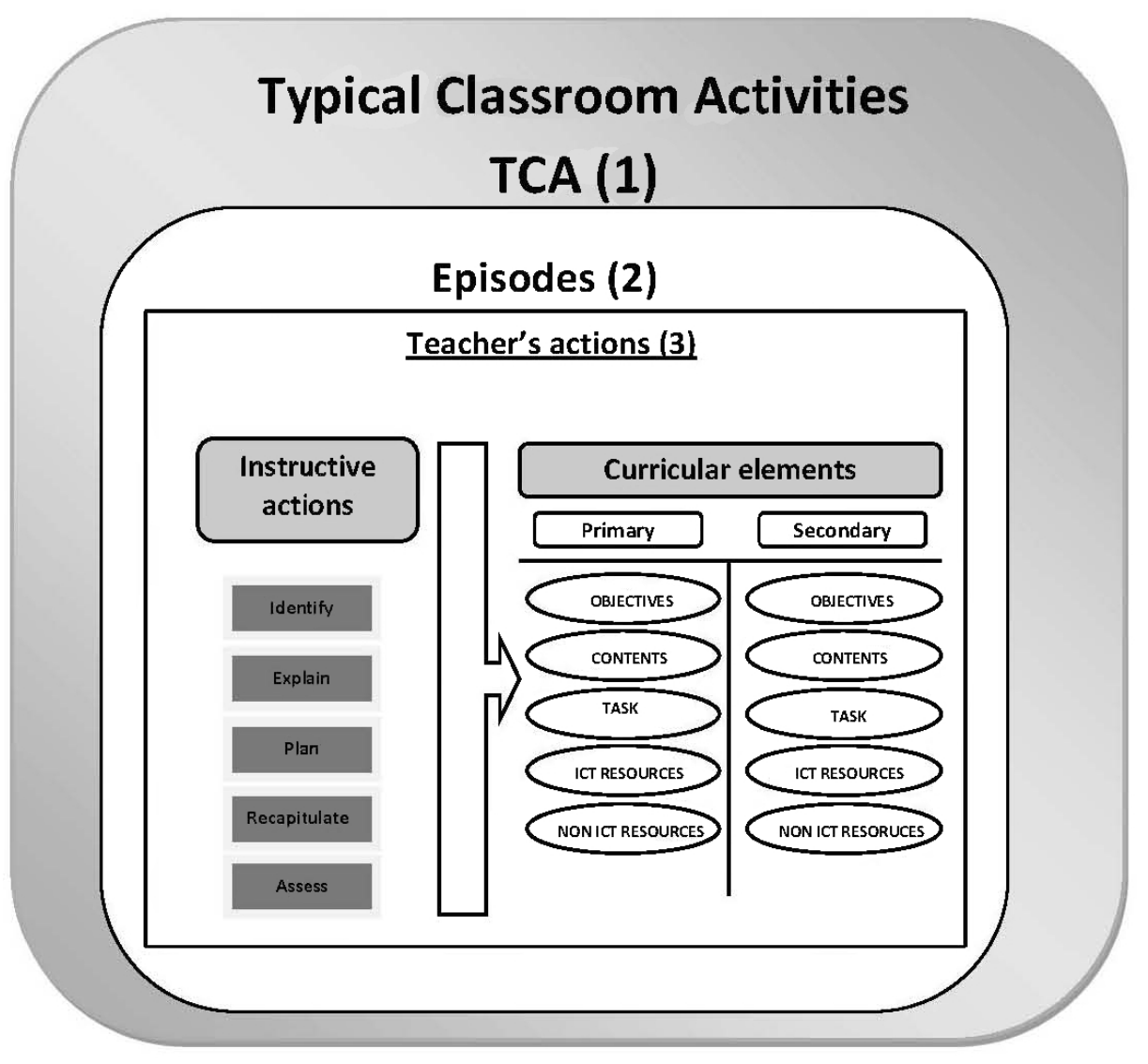

Figure 1: Summary of class analysis procedure

The set of statements or the sample from which the data presented in the results section were obtained is displayed in Tables 1 and 2 below. It includes the final count of the frequencies and percentages obtained in each of the categories of the system of analysis.

Table 1: Frequency of TCA and instructive actions in each TCA

\begin{tabular}{|l|c|c|}
\hline \multicolumn{1}{|c|}{$\begin{array}{c}\text { Typical classroom activity } \\
\text { (TCA) }\end{array}$} & $\begin{array}{c}\text { Frequency of } \\
\text { each TCA (N=16) }\end{array}$ & $\begin{array}{c}\text { Instructive actions in } \\
\text { each TCA (N=431) }\end{array}$ \\
\hline Planning-explanation & 3 & 34 \\
\hline Review of contents & 2 & 42 \\
\hline Task performance (with ICT resource) & 6 & 278 \\
\hline Task performance (with non-digital resource) & 1 & 29 \\
\hline Explanation (with ICT resource) & 1 & 35 \\
\hline Assigning homework & 2 & 4 \\
\hline Review of tasks & 1 & 9 \\
\hline Total & 16 & 431 \\
\hline
\end{tabular}


Table 2: Frequency and percentage of instructive actions and curricular elements

\begin{tabular}{|l|c|c|l|c|c|c|c|}
\multicolumn{1}{c}{$\begin{array}{c}\text { Instructive } \\
\text { actions }\end{array}$} & $\mathrm{f}$ & $\%$ & \multicolumn{2}{c}{$\begin{array}{c}\text { Curricular } \\
\text { elements }\end{array}$} & \multicolumn{2}{c|}{ Primary } & \multicolumn{2}{c|}{ Secondary } \\
\cline { 5 - 8 } & & & & $\mathrm{f}$ & $\%$ & $\mathrm{f}$ & $\%$ \\
\hline Identify & 72 & $16.70 \%$ & Objectives & 1 & $0.23 \%$ & 6 & $2.33 \%$ \\
\hline Plan & 64 & $14.84 \%$ & Contents & 164 & $38.14 \%$ & 44 & $17.13 \%$ \\
\hline Explain & 126 & $29.23 \%$ & Tasks & 173 & $40.23 \%$ & 46 & $17.90 \%$ \\
\hline Recapitulate & 18 & $4.18 \%$ & ICT resource & 89 & $20.70 \%$ & 157 & $61.09 \%$ \\
\hline Supervise-assess & 151 & $35.05 \%$ & Non ICT resource & 3 & $0.70 \%$ & 4 & $1.55 \%$ \\
\hline Total & 431 & $100 \%$ & Total & 430 & $100 \%$ & 257 & $100 \%$ \\
\hline
\end{tabular}

\section{Results}

The presentation of the results is organised around the two issues analysed and will allow us to delimit the role of the ICT resource within the teachers' actions and in relation to their pedagogical knowledge of the subject matter: (a) the methodological strategy guiding the class and the role of the teacher, and $(b)$ the role the teachers give the ICT resource in relation to the rest of the elements of the curriculum.

\section{Methodological strategy and the role of the teacher}

The data in relation to this issue were obtained through an analysis of the TCA and their relation to the instruction the teachers carry out in the class sequences collected. These results are shown in Table 3. The analysis procedure was carried out as described below.

Table 3: Frequency and percentage of observation of the different TCA and instructive actions

\begin{tabular}{|l|c|c|c|c|c|}
\hline \multirow{2}{*}{$\begin{array}{c}\text { Typical classroom activity } \\
\text { (TCA) }\end{array}$} & \multicolumn{4}{|c|}{ Instructive actions } & \multirow{2}{*}{ Total (a) } \\
\cline { 2 - 5 } & Identify & Explain & Plan & Supervise & \\
\hline Planning the class/explanation & 5 & 15 & 1 & 11 & 32 \\
& $(15.6 \%)$ & $(46.9 \%)$ & $(3.1 \%)$ & $(34.4 \%)$ & $(8.6 \%)$ \\
\hline Review of contents & 2 & 8 & 12 & 19 & 41 \\
& $(4.9 \%)$ & $(19.5 \%)$ & $(29.3 \%)$ & $(46.3 \%)$ & $(11.0 \%)$ \\
\hline Task performance with ICT resource & 54 & 76 & 41 & 97 & 268 \\
& $(20.1 \%)$ & $(28.4 \%)$ & $(15.3 \%)$ & $(36.2 \%)$ & $(71.7 \%)$ \\
\hline Explanation with ICT resource & 8 & 9 & 6 & 10 & 33 \\
& $(24.2 \%)$ & $(27.3 \%)$ & $(18.2 \%)$ & $(30.3 \%)$ & $(8.8 \%)$ \\
\hline Total (b) & 69 & 108 & 60 & 137 & 374 \\
& $(18.4 \%)$ & $(28.9 \%)$ & $(16.0 \%)$ & $(36.6 \%)$ & $(100 \%)(\mathrm{c})$ \\
\hline
\end{tabular}

(a) TCA: $\left(\chi_{6}^{2}=906.74 \mathrm{p}<.0001\right)$

(b) Instructive actions: $\left(\chi_{4}^{2}=129.10, \mathrm{p}<.0001\right)$.

(c) TCA $x$ instructive actions: $\left(\chi_{9}^{2}=19.601, p<.0001, w=.225\right)$

In the first place, we confirmed that the different TCA analysed did not have the same probability of occurring. Task performance with ICT $(64.5 \%)$ was the TCA most observed, whereas Assigning homework and Review of tasks took place to a much lesser extent, and in none of the cases did it exceed 5\% (Table 1). Secondly, we found that the different Instructive Actions did not have the same probability of occurring either. Supervision was the Action most observed (36.6\%), and Planning, the least $(16.0 \%)$ (see Table 3). We then proceeded to verify whether there was a relation between the TCA and the Instructive Actions, and found a statistically significant relation, allowing us to affirm that the different Instructive Actions are not employed in the same proportion 
in the different TCA. After analysis of the corrected typified residuals, we considered only those with a significance level under .01, and they are shown in Table 3 . We found more actions of Explanation and fewer of Identification in the TCA of Planning the class/explanation; more of Supervision in those of Review of contents; more of Supervision in that of Task performance with ICT resource; and more of Supervision and Explanation and fewer of Planning in Explanation with ICT resource (Table 3).

\section{Role of ICT resource in relation to the rest of the curricular elements}

The data relating to this issue were obtained through analysis of the TCA and their relation to the primary and secondary elements of the curriculum that teachers addressed in the recorded class sessions. These results are shown in Table 4 (primary elements) and in Figure 2 (secondary elements).

As regards the primary curricular elements, we found that they do not have the same probability of occurring. The Task and the Content appear in a significantly higher proportion $(40.2 \%$ and $39.2 \%$, respectively), than the ICT resources $(20.6 \%)$ or the nonICT objectives ( $0 \%$ ) (see Table 4$)$.

Table 4: Frequency and percentage of observation of TCA and primary curricular elements

\begin{tabular}{|l|c|c|c|c|}
\hline \multirow{2}{*}{$\begin{array}{c}\text { Typical classroom activity } \\
\text { (TCA) }\end{array}$} & \multicolumn{2}{c|}{ Primary curricular elements } & \multirow{2}{*}{ Total (a) } \\
\cline { 2 - 5 } & Content & Task & ICT resource & \\
\hline Planning the class/explanation & 10 & 10 & 14 & 34 \\
& $(29.4 \%)$ & $(29.4 \%)$ & $(41.2 \%)$ & $(8.2 \%)$ \\
\hline Review of contents & 20 & 10 & 11 & 41 \\
& $(48.8 \%)$ & $(24.4 \%)$ & $(26.8 \%)$ & $(9.9 \%)$ \\
\hline Task performance with ICT resource & 122 & 96 & 56 & 274 \\
& $(44.5 \%)$ & $(35 \%)$ & $(20.4 \%)$ & $(66.3 \%)$ \\
\hline Task performance with non-digital resource & 2 & 27 & 0 & 29 \\
& $(6.9 \%)$ & $(93.1 \%)$ & $(0 \%)$ & $(7.0 \%)$ \\
\hline Explanation with ICT resource & 8 & 23 & 4 & 35 \\
& $(22.9 \%)$ & $(65.7 \%)$ & $(11.4 \%)$ & $(8.5 \%)$ \\
\hline Total (b) & 162 & 166 & 85 & 413 \\
& $(39.2 \%)$ & $(40.2 \%)$ & $(20.6 \%)$ & (c) \\
\hline
\end{tabular}

(a) TCA: $\left(\chi_{6}^{2}=906.74 \mathrm{p}<.0001\right)$

(b) Primary curricular elements $\left(\chi_{4}^{2}=322.97, \mathrm{p}<.0001\right)$

(c) TCA x primary curricular elements $\left(\chi_{8}^{2}=60.263, \mathrm{p}<.0001, \mathrm{w}=.373\right)$

To establish the relation between the TCA and the primary curricular elements, we considered only the TCA in which the primary curricular elements observed were sufficient to posit a chi-square test. The results yielded a statistically significant relation, allowing us to confirm that the different primary elements of the curriculum did not appear in the same proportion in the different TCA. Again, we analysed the corrected typified residuals, considering only those whose level of significance was below .01, which are the ones displayed in Table 4 . We found that more elements of ICT resources were observed in Planning the class/explanation, whereas Contents prevailed in the Review of contents. The elements of Contents and Task were more present in Task performance with ICT resource; Tasks predominated over the rest of the elements in Task performance with non-digital resource, and also predominated in Explanation with ICT resource. 
In relation to the role of the secondary curricular elements we proceeded as follows. We verified that that they did not have the same probability of occurring. The ICT resources appear to a much greater extent $(61.09 \%)$ than Tasks $(17.9 \%)$ Contents $(17.12 \%)$, Objectives $(2.33 \%)$ and Non-ICT resources $(1.56 \%)$. However, when considering only those TCA in which the number of secondary curricular elements observed was sufficient for using a chi-square test, all the cells had to be eliminated except those corresponding to the TCA of Task performance with ICT resource. Therefore it was not possible to obtain the relation between the TCA and secondary curricular elements. We can only report the chi-square obtained through the non-parametric test of the secondary curricular elements and the data regarding the percentages of secondary curricular elements in the total observed class sessions (Figure 2).

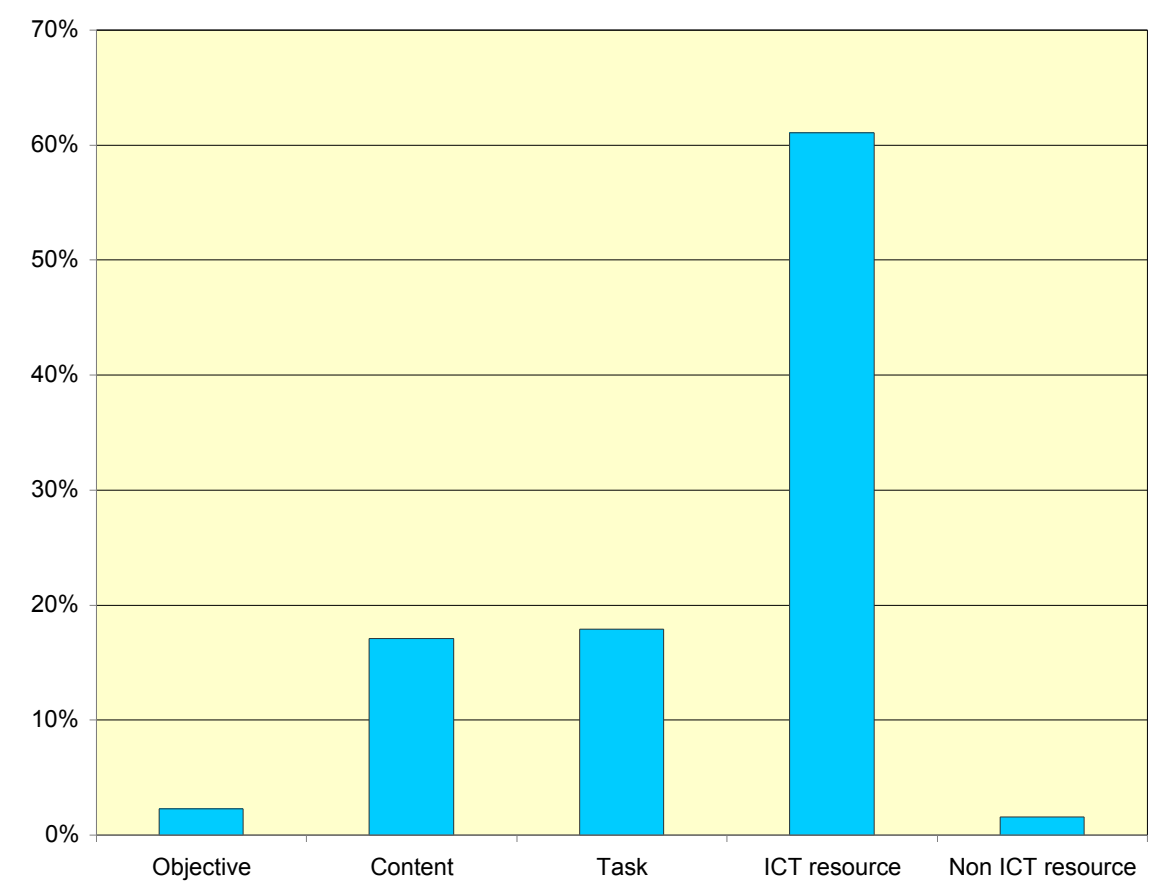

Figure 2: Percentages of observation of the secondary curricular elements

\section{Discussion}

The results presented in the section above reveal several aspects that remain constant for all teachers involved in the study.

Firstly, the methodological strategy underlying their classes was focused on the joint activity of students and teachers. One of the traits revealed by the data analysed is the appearance in all the classes of a typical classroom activity that we call "Task performance with ICT resource." Of the 16 TCA found, six corresponded to this activity and occupy $64.5 \%$ of the total of instructive actions in the classes studied (278 over 431, Table 1). This seems to be a norm of practice relatively common to all the teachers in this study when incorporating Internet resources into their teaching. 
Secondly, the teachers positioned their teaching activity around the TCA used in the classroom, their role being fundamentally one of supervision, followed by their role as explainers. This means that in the sessions recorded, the time was devoted to having the students carry out tasks while the teacher assessed and evaluated how the students were performing them, also explaining the contents and tasks related to student performance, but to a lesser extent. This predominance of supervision followed by explanation seems logical if we take into account the type of TCA prevailing in the teaching practice from which the data were obtained (Task performance with ICT resource).

Thirdly, we can highlight the fact that these practices with Internet-related resources were carried out by teachers acting primarily on two curricular elements: contents and tasks, with the ICT resources as background support. Only in two of the cases did the ICT resources play a leading role: one of them is an episode in which the teacher reorganises the distribution of students and computers due to problems with the Internet connection (Class 3) and the other occurs when the teacher explains how to use the Publisher software (Class 4). It is in this last case, then, when the ICT resource becomes the contents of the class.

In short, if we analyse the data, several issues can be highlighted:

- The repeated appearance of a type of activity that has been called "task performance with ICT resource" in the five classes analysed, regardless of the teacher, type of resource or nature of the lesson being taught.

- The teacher's role in the classes is reflected in the actions of supervision and explanation, which are the main elements in their activity, in close correspondence with the predominant type of TCA.

- The predominance of tasks and contents as the primary focal points of the teachers' actions in their teaching practice, and the incorporation of Internet-associated ICT resources as support elements for action on these contents and activities and thus subordinated to them.

\section{Conclusion}

As we explained in the first section on theoretical suppositions, this study was intended to locate the role of ICT media within the action plans of teachers involved in the study and in relation to their pedagogical knowledge, since we believe that based on these theoretical approaches we can interpret and understand how and why teachers incorporate the use of ICT into their classroom practice.

Our analysis of the data and discussion of the results allow us to draw some conclusions in relation to the theory. First, as regards the teachers' action plans incorporating Internet-related resources, it is clear that tasks and contents are the instruments that direct their action in class. In this sense, our conclusions are no different from the results obtained in studies of teaching practices that did not use ICT resources. This allows us to affirm that, at least in the case of our study, the use of ICT resources does not modify the customary action plans that other studies have described when analysing teaching practice in general. The data have also shown the close relationship between these curricular elements and the Internet-associated resources, and that this relationship subordinates the resource to the teaching tasks, or to the lesson contents, or to both simultaneously. Therefore, we can conclude that, at 
least as far as the teachers involved in our study are concerned, the resource does not define an action plan in teaching practice (Ruthven, Hennessy \& Deaney 2005); rather, it is the tasks and contents that do so, linked secondly to the resource being used.

In second place, and closely related to the above, it can be concluded that it is the pedagogical knowledge of the subject matter in relation to the resource which imbues the use of the resource with meaning in the contexts of practice, at least as regards our study. The analysis of how these five teachers act in class shows us a panorama in which the Internet-associated resource incorporated into each of the practices acquires meaning because it is consistent with the practical action plans that the teachers have regarding the teaching of their subject (Olson, 2003). This consistency is based on the fact that these resources support and maintain the work done involving the tasks or the contents, which are the central focus of the teaching practice. We can thus also conclude that, at least in this study, the incorporation of ICT resources into teaching only makes sense if it is consistent with the execution of the practice, and that consistency has been verified in our study through the analysis of direct teaching practices incorporating ICT resources. It still remains to be seen whether this consistency is a result of knowledge acquired from direct teaching, from observation of other teaching models, or from knowledge acquired during training experiences, among other things.

Thirdly, future research is also needed to study the type of activity we have called "task performance with ICT resource" as a pattern of action of teachers when working with Internet-related digital media. More specifically, the nature of this type of activity, its relation to the use of these resources, to lessons of different subject matter, to different types of teachers, and so on, are issues that can be studied with controlled research designs in which it can be verified whether or not there exist typical instructive sequences in classroom practices incorporating Internet-related ICT resources.

Finally, we must underscore the need for detailed study of real teaching practice in order to be able to explain what is taking place in teaching-learning processes (Dede, Honan \& Peters, 2005; Lawless \& Pelegrino, 2008) and to be able to propose norms of action for change, if considered necessary (Murcia \& Sheffield, 2010). As Olson (2003) pointed out: "Research is needed to find out more about teachers' work culture and the technologies that sustain it, and the implications of new approaches for those technologies" (pp. 51)

\section{Notes}

1. More information on how this system is used to analyse different interactions in reading comprehension can be found in Sánchez, García, Rosales, de Sixte and Castellano (2008) and Sánchez, García, De Sixte, Castellano and Rosales (2008), and for different patterns of actions of teaching practice in this same task see Sánchez, García, de Sixte and Castellano (2008), and Sánchez, García and Rosales, (2010). Other studies in the vein developed by these authors can also be consulted: Chi, Siler, Jeong,Yamauchi and Hausmann (2001); Leinhardt and Steele (2005);

Nystrand, Wu, Gomoran, Zeiser and Long (2003); Polman (2004); Tabak and Baumgartner (2004); Wallace, Kupperman, Krajcik \& Soloway (2000).

2. The original transcriptions were in Spanish. Every example here has been translated by a specialist in scientific translations. 


\section{Acknowledgments}

This research was supported by funds from the Castilla and León Regional Goverment (Reference number: SA060A06).

\section{References}

Baek, Y., Jung, J. \& Kim, B. (2006). What makes teachers use technology in the classroom? Exploring the factors affecting facilitation of technology with a Korean sample. Computers $\mathcal{E}$ Education, 50(1), 224-234. http: / / dx.doi.org/10.1016/j.compedu.2006.05.002

Baskin, C. \& Williams, M. (2006). ICT integration in schools: Where are we now and what comes next? Australasian Journal of Educational Technology, 22(4), 455-473.

http:/ / www.ascilite.org.au/ajet/ajet22/baskin.html

Bate, F. (2010). A bridge too far? Explaining beginning teachers' use of ICT in Australian schools. Australasian Journal of Educational Technology, 26(7), 1042-1061. http: / / www.ascilite.org.au/ajet/ajet26/bate.html

Carter, K. \& Doyle, W. (1987). Teachers' knowledge structures and comprehension processes. In J. Calderhead (Ed.), Exploring teachers' thinking (pp. 147-160). London: Cassell Education.

Cartwright, V. \& Hammond, M. (2007). “Fitting it in”: A study exploring ICT use in a UK primary school. Australasian Journal of Educational Technology, 23(3), 390-407. http:/ / www.ascilite.org.au/ajet/ajet23/cartwright.html

Chi, M., Siler, S. A., Jeong, H., Yamauchi, T. \& Hausmann, R. G. (2001). Learning from human tutoring. Cognitive Science, 25(4), 471-533. http:/ / dx.doi.org/10.1207/s15516709cog2504_1

Clark, C. H. M. (2003). Ten years of conceptual development in research on teacher thinking. In M. Kompf \& P. M. Denicolo (Eds.), Teacher thinking twenty years on: Revisiting persisting problems and advances in education (pp. 211-221). The Netherlands: Swets and Zeitlinger.

Cuban, L. (1993). Computers meet classroom: Classroom wins. Teachers College Record, 95(2), 185210. http:/ / www.tcrecord.org/Content.asp?ContentId=82

Cuban, L. (2001). Oversold and underused: Computers in the classroom. Cambridge, MA: Harvard University Press.

Decree 52/2007, 17 May, art. 5.7 (BCyL 05/23/2007). [ viewed Jan 2010] http: / / bocyl.jcyl.es/html/2007/05/23/html/BOCYL-D-23052007-7.do

Dede, C., Honan, J. P. \& Peters, L. C. (Eds.) (2005). Scaling up success: Lessons from technology-based educational improvement. San Francisco: Jossey-Bass.

Doyle, W. (1987). The classroom as a workplace: Implications for staff development. In M. Wideen \& I. Andrews (Eds.), Staff development for school improvement (pp. 38-54). London: The Falmer Press.

Ellis, A., Hughes, J., Weyers, M. \& Riding, P. (2008). University teacher approaches to design and teaching and concepts of learning technologies. Teaching and Teacher Education, 25(1), 109-117. http: / / dx.doi.org/10.1016/j.tate.2008.06.010

Gimeno, J. (1988). El curriculum: una reflexión sobre la práctica. Madrid: Morata.

Gimeno, J (Ed.) (2010). Saberes e incertidumbres sobre el curriculum. Madrid: Morata. 
Lawless, K. A. \& Pellegrino, J. W. (2007). Professional development in integrating technology into teaching and learning: knowns, unknowns, and ways to pursue better questions and answers. Review of Educational Research, 77, 575-614. http:/ / dx.doi.org/10.3102/0034654307309921

Leinhardt, G. \& Greeno, J. G. (1986). The cognitive skill of teaching. Journal of Educational Psychology, 78(2), 75-95. http: / / dx.doi.org/10.1037/ 0022-0663.78.2.75

Leinhardt, G. \& Steele, M. D. (2005). Seeing the complexity of standing to the side: Instructional dialogues. Cognition and Instruction, 23(1), 87-163. http:/ / dx.doi.org/10.1207/s1532690xci2301_4

Leinhardt, G., Weidman, C. \& Hammond, K. M. (1987). Introduction and integration of classroom routines by expert teachers. Curriculum Inquiry, 17(2), 135-176. http: / / www.jstor.org/ stable/1179622

Lemke, J. (1990). Talking science: Language, learning, and values. Norwood, NJ: Ablex.

Loveless, A. M. (2003). The interaction between primary teachers' perceptions of ICT and their pedagogy. Education and Information Technologies, 8(4), 313-326. http: / / dx.doi.org/ 10.1023/B:EAIT.0000008674.76243.8f

Koehler, M. J. \& Mishra, P. (2009). What is technological pedagogical content knowledge? Contemporary Issues in Technology and Teacher Education, 9(1), 60-70. http: / / www.editlib.org/p/29544

Murcia, K. \& Sheffield, R. (2010). Talking about science in interactive whiteboard classrooms. In M. Thomas \& A. Jones (Eds.), Interactive whiteboards: An Australasian perspective. Australasian Journal of Educational Technology, 26(Special issue, 4), 417-431. http:/ / www.ascilite.org.au/ajet/ajet26/murcia.html

Nystrand, M., Wu, L. L., Gomoran, A., Zeiser, S. \& Long, D. A. (2003). Questions in time: Investigating the structure and dynamics of unfolding classroom discourse. Discourse Processes, 35(2), 135-198. http:/ / dx.doi.org/10.1207/S15326950DP3502_3

Olson, J. K (2003). Information technology and teacher routines: Learning from the microcomputer. In M. Kompf \& P. M. Denicolo (Eds.), Teacher thinking twenty years on: Revisiting persisting problems and advances in education (pp. 45-52). The Netherlands: Swets and Zeitlinger.

Polman, J. L. (2004). Dialogic activity structures for project-based learning environments. Cognition and Instruction, 22(4), 431-466. http: / / dx.doi.org/10.1207/s1532690Xci2204_3

Putnam, R. T. \& Borko, H. (2000). What do new views of knowledge and thinking have to say about research on teacher learning? Educational Researcher, 29(1), 4-15. http: / / dx.doi.org/10.3102/0013189X029001004

Royal Decree 1537/2003, 5 December (BOE 12/10/2003). [viewed Jan 2010] http: / / www.boe.es/ boe/dias / 2003/12/10/pdfs / A43808-43813.pdf

Ruthven, K., Hennessy, S. \& Deaney, R. (2005). Incorporating Internet resources into classroom practice: Pedagogical perspectives and strategies of secondary-school subject teachers. Computers \& Education, 44(1), 1-34. http:/ / dx.doi.org/10.1016/j.compedu.2003.11.001

Sánchez, E., Rosales, J. \& Cañedo, I. (1999). Understanding and communication in expositive discourse: an analysis of the strategies used by expert and preservice teachers. Teaching and Teacher Education, 15(1), 37-58. http:/ / dx.doi.org/10.1016/S0742-051X(98)00033-X

Sánchez, E., García, J. R., Castellano, N., De Sixte, R., Bustos, A. \& García-Rodicio, H. (2008). Qué, cómo y quién: Tres dimensiones para analizar la práctica educativa. Cultura y Educación, 20(1), 95-118. http: / / es.scribd.com/ doc/60357844/Sanchez-et-al-2008-Que-como-quien-tresdimensiones-para-analizar-la-practica-educativa 
Sánchez, E., García, J. R., De Sixte, R., Castellano, N. \& Rosales, J. (2008). El análisis de la práctica educativa y las propuestas instruccionales: Integración y enriquecimiento mutuo. Infancia y Aprendizaje, 31(2), 233-258. http:/ / dx.doi.org/10.1174/021037008784132978

Sánchez, E., García, J. R., Rosales, J., de Sixte, R. \& Castellano, N. (2008). Elementos para analizar la interacción entre estudiantes y profesores: ¿qué ocurre cuando se consideran diferentes dimensiones y unidades de análisis? Revista de Educación, 346, 105-136. http: / / www.revistaeducacion.mec.es / re346_04.html

Sánchez, E., García, R. \& Rosales, J. (2010). La lectura en el aula. Qué se hace, qué se debe hacer y qué se puede hacer. Barcelona: Graó.

Shavelson, R. \& Stern, P. (1983). Investigación sobre pensamiento pedagógico del profesor, sus juicios, decisiones y conducta. In J. Gimeno \& A. Pérez (Eds.), La enseñanza: Su teoría y su práctica (pp. 372-419), Madrid: Akal.

Shulman, J. H. (1986). Those who understand: Knowledge growth in teaching. The Educational Researcher, 15(2), 4-14. http:/ / dx.doi.org/10.3102/0013189X015002004

Shulman, L.S. (1987). Knowledge and teaching: Foundations of the new reform. Harvard Educational Review, 57(1), 1-23. http:/ / her.hepg.org/content/j463w79r56455411/ ?p=b34e90 bd653642a889110338b933a9df\&pi=0

Tillema, H. (1984). Categories in teacher planning. In R. Halkes \& J. K. Olson (Eds.), Teacher thinking (pp. 176-185). Lisse: Swets and Zeitlinger.

Tabak, I. \& Baumgartner, E, (2004). The teacher as partner: Exploring participant structures, symmetry, and identity work in scaffolding. Cognition and Instruction, 22(4), 303-429. http: / / dx.doi.org/10.1207/s1532690Xci2204_2

Wallace, R., Kupperman, J., Krajcik, J. \& Soloway, E. (2000). Science on the web: Students online in a sixth-grade classroom. Journal of the Learning Sciences, 9(1), 75-104. http: / / dx.doi.org/10.1207/s15327809jls0901_5

Wells, J. G. (2007). Key design factors in durable instructional technology professional development. Journal of Technology and Teacher Education, 15(1), 101-122. http: / / www.editlib.org/p/6057

Windschitl, M. (2004). What types of knowledge do teachers use to engage learners in "doing science"? Paper commissioned by the National Academy of Sciences. Washington, DC: Board of Science Education. http: / / www7.nationalacademies.org/bose/ mwindschitl_ comissioned_paper_6_03_04_hslabs_mtg.pdf

Yinger, R. J. (1977). A study of teacher planning: Description and theory development using ethnography and information processing methods. Michigan State University, Doctoral Disertation.

Yinger, R. J. (1987). Learning the language of practice. Curriculum Inquiry, 17(3), 293-318. http: / / www.jstor.org/ stable/1179695

Zahorik, J. A. (1975). Teachers' planning models. Educational Leadership, 33, 134-139. http: / / www.ascd.org/ASCD/pdf/journals/ed_lead/el_197511_zahorik.pdf

Zhao, Y., Frank, K. A. \& Ellefson, N. C. (2006), Fostering meaningful teaching and learning with technology: Characteristics of effective professional development. In E. A. Ashburn \& R. E. Floden (Eds), Meaningful learning using technology: What educators need to know and do (pp.161179). New York: Teachers College Press. 
Appendix: Participants and classes - structural and organisational data

\begin{tabular}{|c|c|c|c|c|c|c|}
\hline Classes & $\begin{array}{l}\text { Class loc- } \\
\text { ation and } \\
\text { lesson topic }\end{array}$ & $\begin{array}{l}\text { Location and } \\
\text { number of } \\
\text { computers }\end{array}$ & $\begin{array}{l}\text { Res- } \\
\text { ource } \\
\text { employ- } \\
\text { ed }\end{array}$ & $\begin{array}{l}\text { How often } \\
\text { the resource is } \\
\text { used over the } \\
\text { academic } \\
\text { year. Reasons }\end{array}$ & $\begin{array}{c}\text { Attitude } \\
\text { towards and } \\
\text { training in } \\
\text { ICT }\end{array}$ & $\begin{array}{l}\text { Techn- } \\
\text { ical } \\
\text { problems } \\
\text { with the } \\
\text { resource }\end{array}$ \\
\hline $\begin{array}{l}1 . \\
\text { Teacher of } \\
\text { English as a } \\
\text { Foreign } \\
\text { Language. } \\
\text { 1st year } \\
\text { Compul- } \\
\text { sory Sec- } \\
\text { ondary Ed. } \\
\text { (aged 13). }\end{array}$ & $\begin{array}{l}\text { Special } \\
\text { classroom } \\
\text { for art and } \\
\text { technology } \\
\text { equipped } \\
\text { with digital } \\
\text { blackboard. } \\
\text { Topic: The } \\
\text { Present } \\
\text { Continuous } \\
\text { Verb Tense }\end{array}$ & $\begin{array}{l}\text { One computer } \\
\text { for the teacher } \\
\text { connected to a } \\
\text { digital } \\
\text { blackboard } \\
\text { and projector } \\
\text { (total students: } \\
\text { 24). }\end{array}$ & $\begin{array}{l}\text { Internet } \\
\text { page } \\
\text { with } \\
\text { song in } \\
\text { English } \\
\text { plus } \\
\text { digital } \\
\text { black- } \\
\text { board. }\end{array}$ & $\begin{array}{l}\text { Not very often } \\
\text { because special } \\
\text { classroom not } \\
\text { often available. }\end{array}$ & $\begin{array}{l}\text { Very favorable } \\
\text { attitude } \\
\text { towards use of } \\
\text { ICT. } \\
\text { Training in } \\
\text { ICT use at the } \\
\text { local Teacher } \\
\text { Resource and } \\
\text { Training } \\
\text { Center. }\end{array}$ & $\begin{array}{l}\text { Sound not } \\
\text { in step } \\
\text { with the } \\
\text { video } \\
\text { sequence. }\end{array}$ \\
\hline $\begin{array}{l}\text { 2. } \\
\text { Teacher of } \\
\text { Mathem- } \\
\text { atics. } \\
\text { 2nd yr } \\
\text { Compul- } \\
\text { sory } \\
\text { Secondary } \\
\text { Ed. (aged } \\
14) \text {. } \\
\end{array}$ & $\begin{array}{l}\text { Mathem- } \\
\text { atics: slow } \\
\text { track curric- } \\
\text { ulum. } \\
\text { Topic: } \\
\text { Geometry. } \\
\text { Pythagoras' } \\
\text { Theorem } \\
\text { and Class- } \\
\text { ification of } \\
\text { polygons. }\end{array}$ & $\begin{array}{l}\text { Special Ed. } \\
\text { classroom. } \\
\text { Three } \\
\text { computers - } \\
\text { one per } \\
\text { student (total } \\
\text { students: } 3) .\end{array}$ & $\begin{array}{l}\text { Math } \\
\text { exercises } \\
\text { selected } \\
\text { from a } \\
\text { web } \\
\text { page. }\end{array}$ & $\begin{array}{l}\text { All Friday } \\
\text { sessions } \\
\text { throughout the } \\
\text { academic year. } \\
\text { Used to } \\
\text { reinforce } \\
\text { contents } \\
\text { learned during } \\
\text { the week. }\end{array}$ & $\begin{array}{l}\text { Very favorable } \\
\text { attitude } \\
\text { towards use of } \\
\text { ICT. } \\
\text { Mainly self- } \\
\text { taught }\end{array}$ & $\begin{array}{l}\text { No } \\
\text { technical } \\
\text { problems. }\end{array}$ \\
\hline \begin{tabular}{|l|}
3. \\
Teacher of \\
Spanish \\
Language. \\
3rd yr Com- \\
pulsory Sec- \\
ondary Ed. \\
(aged 15).
\end{tabular} & $\begin{array}{l}\text { Drawing } \\
\text { Classroom } \\
\text { with } 12 \\
\text { computers. } \\
\text { Topic: } \\
\text { Journalistic } \\
\text { language. }\end{array}$ & $\begin{array}{l}\text { Not the reg- } \\
\text { ular classroom } \\
\text { but rather the } \\
\text { Drawing } \\
\text { Classroom: } 12 \\
\text { computers. 2-3 } \\
\text { students per } \\
\text { computer (tot. } \\
\text { students: } 22)\end{array}$ & $\begin{array}{l}\text { Web sites } \\
\text { with } \\
\text { digital } \\
\text { press. }\end{array}$ & $\begin{array}{l}\text { Sporadically, } \\
\text { once or twice a } \\
\text { trimester, } \\
\text { because } \\
\text { classrooms } \\
\text { with } \\
\text { computers are } \\
\text { not readily } \\
\text { available. }\end{array}$ & $\begin{array}{l}\text { Positive } \\
\text { attitude } \\
\text { towards the } \\
\text { use of ICT. } \\
\text { Self-taught } \\
\text { and teacher } \\
\text { training } \\
\text { courses. }\end{array}$ & $\begin{array}{l}\text { Problems } \\
\text { in several } \\
\text { computers } \\
\text { with boot- } \\
\text { ing up and } \\
\text { connecting } \\
\text { to the } \\
\text { Internet. }\end{array}$ \\
\hline $\begin{array}{l}4 . \\
\text { Teacher of } \\
\text { Latin. } \\
\text { 1st year } \\
\text { Upper } \\
\text { Secondary } \\
\text { Ed. (aged } \\
17) \text {. }\end{array}$ & $\begin{array}{l}\text { Ordinary } \\
\text { classroom. } \\
\text { Topic: } \\
\text { Games and } \\
\text { public } \\
\text { spectacles in } \\
\text { Ancient } \\
\text { Rome. }\end{array}$ & $\begin{array}{l}3 \text { computers: } \\
\text { one for teach- } \\
\text { ing connected } \\
\text { to a projector } \\
\text { and two lap- } \\
\text { tops for stud- } \\
\text { ent use. All } \\
\text { connected to } \\
\text { the Internet } \\
\text { (total students: } \\
\text { 2). }\end{array}$ & $\begin{array}{l}\text { Web- } \\
\text { Quest } \\
\text { made by } \\
\text { the } \\
\text { teacher. }\end{array}$ & $\begin{array}{l}\text { Quite regularly } \\
\text { due to the } \\
\text { teacher's } \\
\text { interest in } \\
\text { working with } \\
\text { ICT. }\end{array}$ & $\begin{array}{l}\text { Very favorable } \\
\text { towards the } \\
\text { introduction of } \\
\text { ICT. } \\
\text { Self-taught } \\
\text { and training } \\
\text { courses esp. in } \\
\text { editing digital } \\
\text { video. }\end{array}$ & $\begin{array}{l}\text { No } \\
\text { technical } \\
\text { problems. }\end{array}$ \\
\hline
\end{tabular}




\begin{tabular}{|c|c|c|c|c|c|c|}
\hline $\begin{array}{l}5 . \\
\text { Teacher of } \\
\text { Philosophy. } \\
\text { 1st year } \\
\text { Upper } \\
\text { Secondary } \\
\text { Ed. (aged } \\
17) \text {. }\end{array}$ & $\begin{array}{l}\text { Computer } \\
\text { Room } \\
\text { Topic: The } \\
\text { controversy } \\
\text { surround- } \\
\text { ing the } \\
\text { Theory of } \\
\text { Evolution } \\
\text { and Creat- } \\
\text { ionism. }\end{array}$ & $\begin{array}{l}10 \text { computers } \\
\text { connected to } \\
\text { the Internet, } \\
\text { plus one } \\
\text { connected to a } \\
\text { projector for } \\
\text { teaching (total } \\
\text { students: } 21) \text {. }\end{array}$ & $\begin{array}{l}\text { Digitalis- } \\
\text { ed video } \\
\text { frag- } \\
\text { ments } \\
\text { and } \\
\text { Internet } \\
\text { search } \\
\text { engines. }\end{array}$ & $\begin{array}{l}\text { Not often } \\
\text { because the } \\
\text { computer } \\
\text { room is not } \\
\text { readily } \\
\text { available due } \\
\text { to high } \\
\text { occupation. }\end{array}$ & $\begin{array}{l}\text { Very favorable } \\
\text { towards the } \\
\text { introduction of } \\
\text { ICT. } \\
\text { Initial training } \\
\text { when studying } \\
\text { at the } \\
\text { University. }\end{array}$ & $\begin{array}{l}\text { At first the } \\
\text { projector } \\
\text { did not } \\
\text { work. }\end{array}$ \\
\hline
\end{tabular}

Authors: Dr Elena Ramírez (Corresponding author), Professor

Facultad de Educación, University of Salamanca

Paseo de Canalejas, 169, 37008-Salamanca, Spain

Email: ero@usal.es

Dr Maria Clemente, Full Professor

Facultad de Educación, University of Salamanca

Paseo de Canalejas, 169, 37008-Salamanca, Spain

Email:mcl@usal.es

Dr Isabel Cañedo, Professor

Facultad de Educación, University of Salamanca

Paseo de Canalejas, 169, 37008-Salamanca, Spain

Email: icado@usal.es

Jorge Martin, Fellowship at the University of Salamanca

Facultad de Educación, University of Salamanca

Paseo de Canalejas, 169, 37008-Salamanca, Spain

Email: jorgemd@usal.es

Please cite as: Ramírez, E., Clemente, M., Cañedo, I. \& Martin, J. (2012). Incorporating Internet resources into classroom practice: Secondary school teacher action plans.

Australasian Journal of Educational Technology, 28(8), 1433-1450.

http:/ / www.ascilite.org.au/ajet/ajet28/ramirez.html 